\title{
Localization of BRCA1 protein in breast cancer tissue and cell lines with mutations
}

\author{
Natalie Tulchin ${ }^{1 *}$, Leonard Ornstein ${ }^{1}$, Steven Dikman ${ }^{1}$, James Strauchen ${ }^{1}$, Shabnam Jaffer ${ }^{1}$, Chandandeep Nagi ${ }^{1}$,

 \\ Monique Chambon ${ }^{5}$, Nicholas T Woods ${ }^{6,7}$ and Alvaro NA Monteiro ${ }^{6}$
}

\begin{abstract}
Background: The breast and ovarian cancer susceptibility gene (BRCA1) encodes a tumor suppressor. The BRCA1 protein is found primarily in cell nuclei and plays an important role in the DNA damage response and transcriptional regulation. Deficiencies in DNA repair capabilities have been associated with higher histopathological grade and worse prognosis in breast cancer.

Methods: In order to investigate the subcellular distribution of BRCA1 in tumor tissue we randomly selected 22 breast carcinomas and tested BRCA1 protein localization in frozen and contiguous formalin-fixed, paraffin embedded (FFPE) tissue, using pressure cooker antigen-retrieval and the MS110 antibody staining. To assess the impact of BRCA1 germline mutations on protein localization, we retrospectively tested 16 of the tumor specimens to determine whether they contained the common Ashkenazi Jewish founder mutations in BRCA1 (185delAG, 5382insC), and BRCA2 (6174delT). We also compared co-localization of BRCA1 and nucleolin in MCF7 cells (wild type) and a mutant BRCA1 cell line, HCC1937 (5382insC).

Results: In FFPE tissue, with MS110 antibody staining, we frequently found reduced BRCA1 nuclear staining in breast tumor tissue compared to normal tissue, and less BRCA1 staining with higher histological grade in the tumors. However, in the frozen sections, BRCA1 antibody staining showed punctate, intra-nuclear granules in varying numbers of tumor, lactating, and normal cells. Two mutation carriers were identified and were confirmed by gene sequencing. We have also compared co-localization of BRCA1 and nucleolin in MCF7 cells (wild type) and a mutant BRCA1 cell line, HCC1937 (5382insC) and found altered sub-nuclear and nucleolar localization patterns consistent with a functional impact of the mutation on protein localization.

Conclusions: The data presented here support a role for BRCA1 in the pathogenesis of sporadic and inherited breast cancers. The use of well-characterized reagents may lead to further insights into the function of BRCA1 and possibly the further development of targeted therapeutics.
\end{abstract}

Keywords: Breast cancer, BRCA1 mutations, Frozen section immunohistology, Nucleolar localization

\section{Background}

Germline mutations in the breast cancer tumor suppressor genes $B R C A 1[1-3]$ and $B R C A 2[4,5]$ have been found in familial breast and ovarian cancer. Prevalence of mutations in patients aged 20 to 74 years with breast cancer were reported to be $3.3 \%$; a finding which did not provide support for screening of the general population [6]. Breast

\footnotetext{
* Correspondence: natalietulchin2@gmail.com

'Department of Pathology, Mount Sinai School of Medicine, 1 Gustave L. Levy Place, New York, NY 10029, USA

Full list of author information is available at the end of the article
}

cancer patients aged 35 years or younger and individuals less than age 45 with first-degree family history of breast cancer had mutation prevalence of about 6.5 and 7\%, respectively [7]. Lidereau et al. [8] found they could improve the likelihood of detecting BRCA1 mutations in a series of patients with invasive breast cancer, under 35 years of age, when they selected patients with estrogen receptor (ER) negative, high grade tumors (37\%). Approximately $2 \%$ of Ashkenazi Jews carry mutations in BRCA1 or BRCA2 that confer, at age 70 , an estimated risk of breast cancer of $56 \%$ $[9,10]$. However, somatic BRCA1 mutations have not been
C Biomed Central 
found in sporadic breast cancer tumor tissue [3,6] although as a tumor suppressor it is thought that BRCA1 participates in tumorigenesis through reduction in BRCA1 mRNA, protein levels, and changes in BRCA1 promoter methylation [11-17]. Recently, BRCA1 mutations have been shown to render breast cancer tumors sensitive to poly (ADP-ribose) polymerase (PARP) inhibition [18]. Sensitivity to PARP inhibitors is thought to be due to a synthetic lethal combination of the inhibitor-induced single-strand break repair deficiency along with loss of the homologous recombination (HR) function of BRCA1 [19].

BRCA1 protein immunohistological staining with the MS110 antibody has shown a speckled nuclear pattern in many breast and ovarian cancer cell lines, as well as in centrosomes and mitochondria [20,21]. Scully et al. [22] described nuclear staining in breast and ovarian cancer cell lines with four monoclonal anti-BRCA1 antibodies and after microwave heating of neutral buffered FFPE sections of primary invasive ductal carcinomas. However, Chen et al. [23] described anti-BRCA1 antibodies which detected cytoplasmic staining in a variety of normal and cancer cell lines, and mixed cytoplasmic and nuclear staining in FFPE breast cancer tissues. Wilson et al. [24] tested 19 anti-BRCA1 antibodies which detected a $220 \mathrm{kD}$ protein localized to nuclear foci in epithelial cell lines from breast malignancies. In FFPE specimens, more uniform nuclear staining was observed in benign breast, invasive lobular cancers, and low grade ductal cancer, while less or absent staining was found in the majority of high-grade ductal carcinomas and breast cancer tissue from patients with BRCA1 185 del AG mutations. However, BRCA1 protein staining remains controversial because of questions about the specificity of antibodies, variations in staining protocols, and staining of lymphocytes in surrounding stromal tissue [25].

Our previous studies have shown that BRCA1 protein is localized in tumor cell nuclei and nucleoli in frozen tissue sections, and is co-localized with nucleolin in MCF7 and HeLa cells [26,27]. Chambon et al. [28] have shown in light and electron microscopic studies of estradiol-treated MCF7 cells that BRCA1 nuclear staining was found in dots around nucleoli, and in the cytoplasm in multivesicular bodies near the Golgi.

In the present study, we show similarities and concordance of BRCA1 protein localization between frozen and pressure cooker antigen-retrieved FFPE tissue in 22 randomly selected breast carcinomas. We further characterized our randomly selected population, by retrospectively genotyping 16 of our anonymized samples for Ashkenazi Jewish mutations BRCA1 (185delAG, 5382insC) and $B R C A 2$ (6174delT). We found two specimens with mutations, one from patient no. 4, with a BRCA2 (6174delT) mutation, and one from patient no. 13, with a BRCA1 (185delAG) mutation, which were subsequently confirmed by DNA sequencing. With immunofluorescence staining and confocal microscopy, we were able to detect BRCA1 sub-nuclear localization in frozen breast cancer tissue specimens and co-localization of BRCA1 and nucleolin in MCF7 (hemizygous for BRCA1 wild type), and HCC1937 (BRCA1 5382insC) cells.

\section{Results}

We found variable BRCA1 protein immunostaining in tumor cell nuclei in frozen tissue sections with the AP16 and K-18 antibodies and with the MS110 antibody in contiguous FFPE tissues of randomly selected breast carcinomas (Table 1, Figures 1, 2, 3, 4, 5, 6 and 7). In frozen sections, we found variable punctate nuclear staining (Figures 1, 2, 6, and 7) and we show distinct nuclear staining, and moderate staining in Figure 4. There was concordance between frozen and FFPE section staining in tumor cell nuclei amongst the histological types, with

Table 1 Tumor genotype and BRCA1 staining

\begin{tabular}{|c|c|c|c|c|c|}
\hline \multirow[t]{2}{*}{ \#Specimen } & \multirow[t]{2}{*}{ Histology } & \multicolumn{2}{|c|}{ BRCA1 } & \multirow{2}{*}{$\begin{array}{l}\text { ER/ } \\
\text { PR }\end{array}$} & \multirow[t]{2}{*}{ Genotype } \\
\hline & & $\overline{\text { FS }}$ & $\overline{\text { FFPE }}$ & & \\
\hline 1. & PDA & +++ & N.A. & $-/+$ & N.T.M. \\
\hline 2. & MDA & ++ & +++ & $+/+$ & N.T.M. \\
\hline 3. & PDA & +++ & ++ & $+/+$ & N.T.M. \\
\hline \multirow[t]{2}{*}{4.} & PDA & +++ & ++++ & $-1-$ & BRCA2 \\
\hline & & & & & 6174delT \\
\hline 5. & PDA & ++++ & +++ & $+/+$ & N.T.M. \\
\hline 6. & MDA & ++ & ++ & $+/+$ & N.T.M. \\
\hline 7. & MDA,lob & ++ & ++ & $+/+$ & N.T.M. \\
\hline 8. & PDA & ++ & +++ & $+/-$ & N.A. \\
\hline 9. & Medullary & ++ & N.A. & $-1-$ & N.A. \\
\hline 10. & Mixed,lob\& duct. & ++++ & ++++ & $+/-$ & N.T.M. \\
\hline 11. & PDA & ++ & + & $-1-$ & N.T.M. \\
\hline 12. & MDA-PDA & ++ & ++ & $+/+$ & N.T.M. \\
\hline \multirow[t]{2}{*}{13.} & PDA & ++ & + & $-1-$ & BRCA1 \\
\hline & & & & & 185delAG \\
\hline 14. & MDA-PDA & +++ & +++ & $+/+$ & N.T.M. \\
\hline 15. & PDA & ++ & + & $+/+$ & N.T.M. \\
\hline 16. & Lobular & +++ & +++ & $+/+$ & N.A. \\
\hline 17. & PDA & ++ & ++ & $+/-$ & N.A. \\
\hline 18. & MDA & +++ & +++ & $+/+$ & N.A. \\
\hline 19. & MDA & ++ & ++ & $+/-$ & N.A. \\
\hline 20. & MDA-PDA & ++ & ++++ & $+/+$ & N.T.M. \\
\hline 21. & PDA & ++ & ++ & $-1-$ & N.T.M. \\
\hline 22. & PDA & ++ & ++ & $+/+$ & N.T.M. \\
\hline
\end{tabular}

$\mathrm{ER} / \mathrm{PR}=$ Estrogen/Progesterone Receptor. $M D A=$ Moderately differentiated adenocarcinoma.

$\mathrm{PDA}=$ Poorly differentiated adenocarcinoma.

N.A. $=$ not available.

N.T.M. $=$ no targeted mutations. 


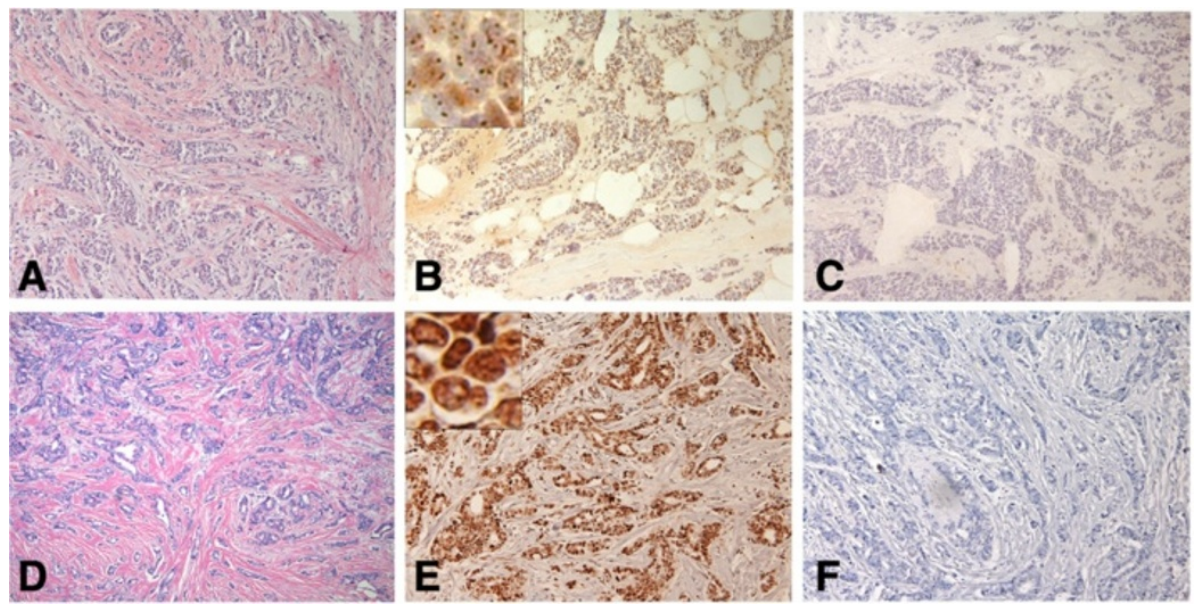

Figure 1 BRCA1 protein in frozen and FFPE sections of moderately differentiated adenocarcinoma (MDA) from patient no. 2. A. H\&E stained frozen section of the tumor. B. Consecutive section of the same tumor stained with the mouse monoclonal AP16 antibody and the avidin-biotin peroxidase detection system showed that many of the cells exhibited multifocal dot-like nuclear staining of category (2); insert shows subnuclear foci. C. Negative control section using standard dilutions of mouse lgG showed essentially no staining. D. H\&E section of FFPE tissue from patient no. 2. E. Consecutive section of the same tumor treated with pressure cooker antigen retrieval and stained with the MS110 antibody showed that most of the cells exhibited moderate nuclear staining of category (3); insert shows dark staining. F. Consecutive control section of FFPE tissue without primary antibody. $(\times 200)$ inserts $(\times 2000)$.

less staining with higher histopathological grade (Table 1). In FFPE stained tumor tissue, the majority of the poorly differentiated adenocarcinomas (PDAs) were in the weak, faint, (1), or distinct (2) staining categories, and less in the moderate (3), and strong (4) staining group. The MDA-PDA, and MDA, lobular specimens showed more elevated levels of staining in both frozen and FFPE sections (Table 1).
In some of our samples, we found less positive BRCA1 nuclear staining in FFPE breast tumor tissue compared to normal tissue as in this example from patient no.19 (Figure 3).We also found strongly stained normal tissue in specimens nos. 2, 15, 20, and 22; however, we found weakly stained normal tissue from patients nos. 13, and 17 .

In our 16 anonymized frozen tissue samples tested for BRCA Ashkenazi founder mutations, we detected

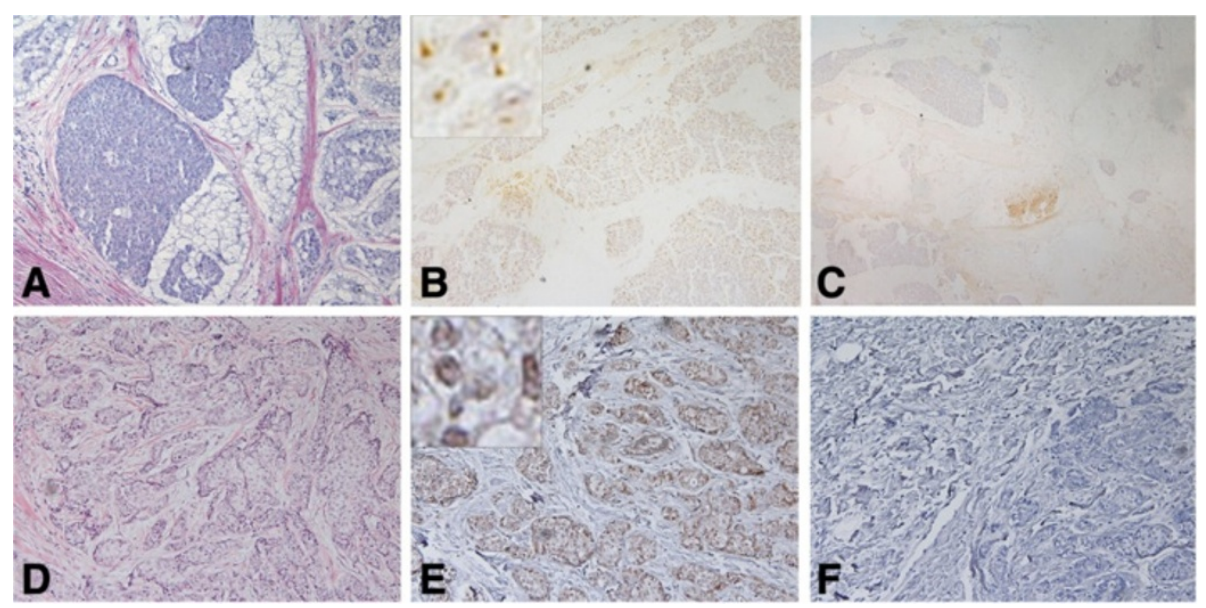

Figure 2 BRCA1 protein in frozen and FFPE sections of moderately differentiated, lobular carcinoma (MDA-lob) from patient no.7. A. H\&E stained frozen section of tumor. B. Consecutive section of the same tumor stained with mouse monoclonal AP16 antibody and biotinylated anti-mouse IgG and avidin-biotin-peroxidase detection system showed that many of the cells showed distinct, punctate nuclear staining of category (2); insert shows focal staining. C. Standard dilution of mouse lgG served as a negative control. D. H\&E section of FFPE tissue from patient no.7. E. Consecutive section of the same tumor treated with pressure cooker antigen retrieval and stained with the MS110 antibody showed that many of the cells exhibited distinct nuclear staining (2); insert shows light staining. F. Consecutive control section of FFPE tissue without primary antibody. $(\times 200)$ insert $(\times 2000)$. 


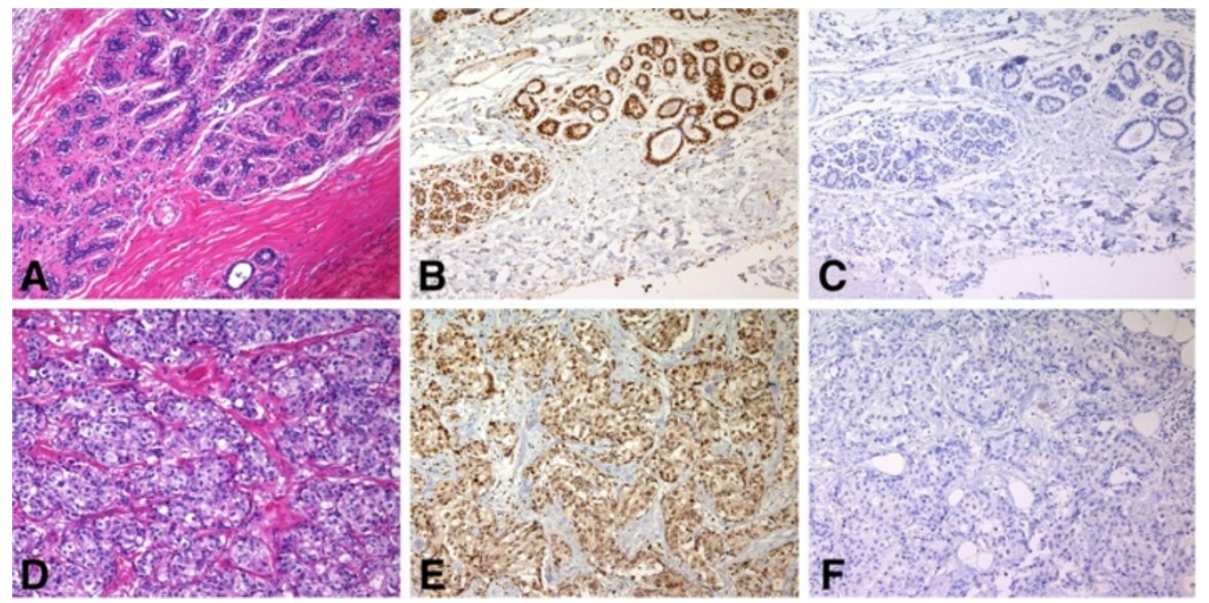

Figure 3 BRCA1 protein localization in normal and tumor FFPE sections of poorly differentiated adenocarcinoma (PDA) from patient no.19. A. H\&E section of FFPE normal tissue. B. Consecutive section of the normal tissue stained with the MS110 antibody showed strong epithelial cell nuclear staining. C. Consecutive control section of FFPE tissue without primary antibody. D. H\&E section of FFPE tumor tissue. E. Consecutive section of the same tumor treated with pressure cooker antigen retrieval and stained with the MS110 antibody showed that many of the cells exhibit distinct nuclear staining (2). F. Consecutive control section of FFPE tissue without primary antibody. (×200).

two mutation carriers: patient no. 4 who was a mutation carrier for BRCA2 (6174delT), and patient no. 13 who was a mutation carrier for BRCA1 (185delAG). No targeted mutations were found in the other 14 samples $(1,2,3,5,6,7,10,11,12,14,15,20,21$, and 22). Six samples were not available $(8,9,16,17,18$, and 19).We assayed BRCA1 immunohistology in our specimens, including those from patients no. 4 and 13 before testing their mutation status. In the frozen sections from patient no. 4, there was moderate (3) BRCA1 nuclear staining in the tumor cells, as well as in the surrounding lactating breast tissue (Figure 5). The contiguous FFPE tissue from patient no. 4 expressed strong (4) BRCA1 nuclear staining in the tumor and in the lactating ducts (Figures 4 and 5).

In contrast, we found diffuse, and irregular but distinct (2) BRCA1 protein staining with the K-18 antibody, in frozen tumor tissue from patient no. 13 with the BRCA1 mutation (Figure 6) The contiguous FFPE tissue stained with the MS110 antibody was only very weakly stained
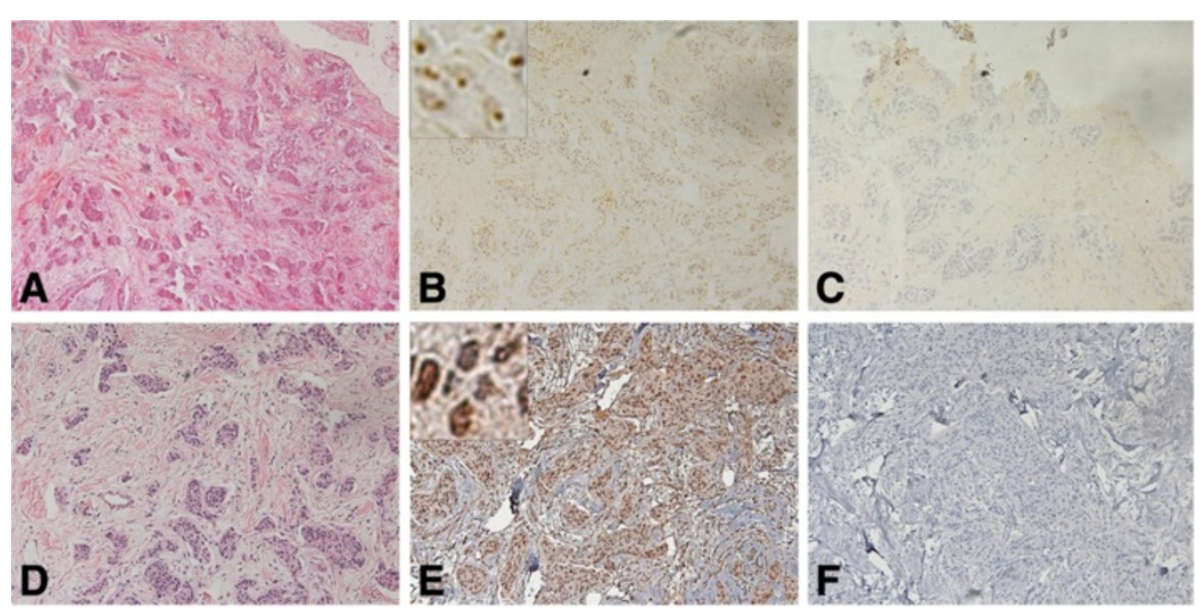

Figure 4 BRCA1 protein in frozen and FFPE sections of poorly differentiated adenocarcinoma (PDA) from patient no. 4 with a $B R C A 2$ (6174delT) mutation. A. H\&E stained frozen section of the tumor. B. Consecutive section of the same tumor stained with the mouse monoclonal AP16 antibody and the avidin-biotin peroxidase detection system showed that many of the cells exhibited moderate punctate nuclear staining (3); insert shows focal staining. C. Negative control section using standard dilutions of mouse lgG. D. H\&E section of FFPE tissue from patient no.4. E. Consecutive section of the same tumor treated with pressure cooker antigen retrieval and stained with the MS110 antibody showed that most of the cells exhibited strong nuclear staining (4), and insert shows strong staining. F. Consecutive control section of FFPE tissue without primary antibody. (×200) insert (×2000). 


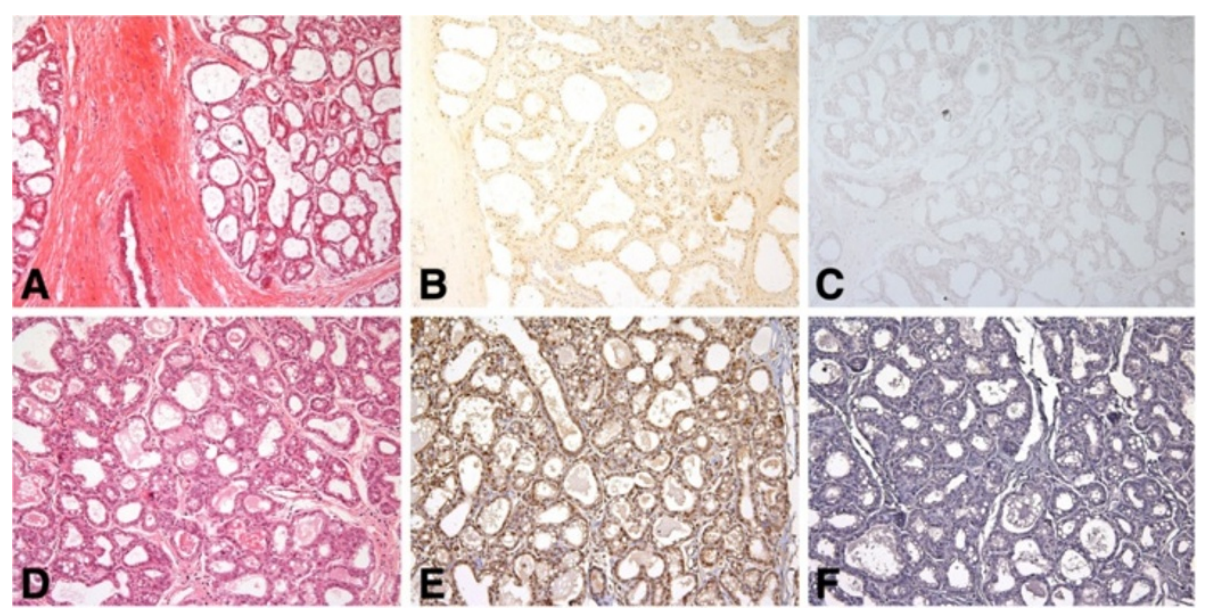

Figure 5 BRCA1 protein in frozen and FFPE sections from lactating tissue from patient no.4 with a BRCA2 mutation. A. H\&E stained frozen section of lactating tissue. B. Consecutive section of the same tissue stained with the mouse monoclonal AP16 antibody and the avidinbiotin peroxidase detection system showed that many of the lactating cells showed punctate nuclear granules. C. Negative control section using standard dilutions of mouse IgG. D. H\&E section of FFPE lactating tissue. E. Consecutive section of the same tissue treated with pressure cooker antigen retrieval and stained with the MS110 antibody showed that most of the lactating cells exhibited moderate homogeneous nuclear staining (3). F. Consecutive control section of FFPE tissue without primary antibody. (×200).

(1) (Figure 6). In the chromatogram (Figure 8), the BRCA1 185delAG mutation in the contiguous paraffin sample for patient no. 13, is compared to the normal sequence in patient no. 12. Neither of the tumors from patient no. 4 or from patient no. 13 showed loss of heterozygosity $(\mathrm{LOH})$ by homozygosity of the mutant allele, as determined by PCR of the amplified fragments (data not shown).
After assessing BRCA1 protein staining by histopathological grade, we further grouped our BRCA1 protein staining results by ER/PR status (Table 1). PDA samples comprised eight out of ten specimens that were either ER or PR negative, or were both ER/PR negative, although the data are too few to permit statistical significance. In addition, two of the ER/PR negative PDAs were mutation carriers (Table 1). It is also interesting to
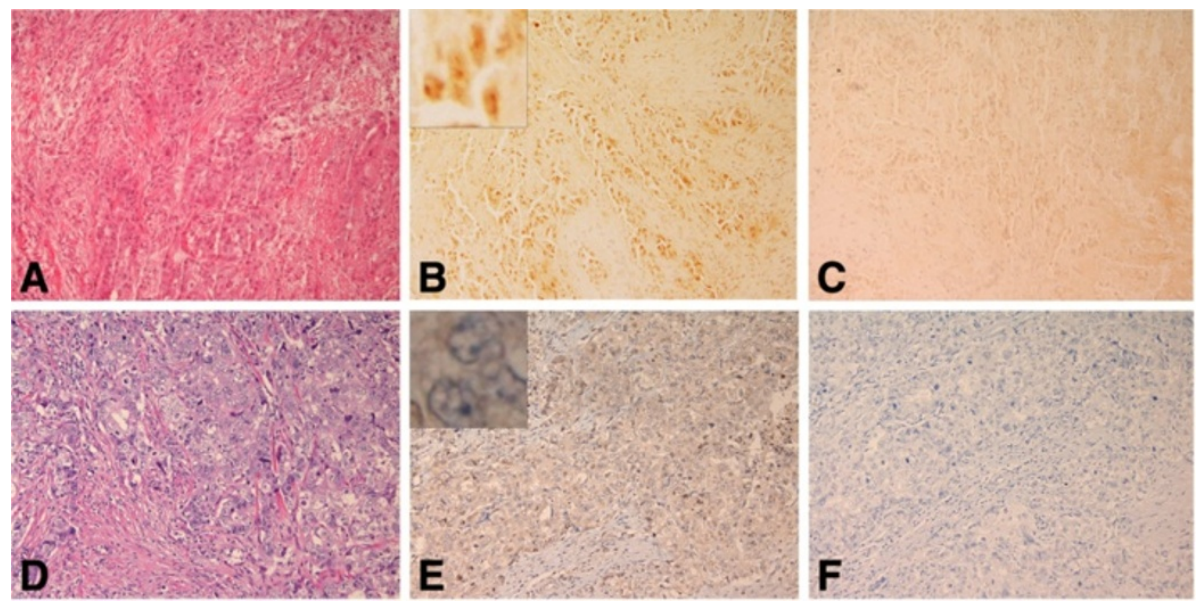

Figure 6 BRCA1 protein in frozen and FFPE sections of poorly differentiated adenocarcinoma (PDA) from patient no.13 with a BRCA1 mutation (185delAG). A. H\&E stained frozen section of the tumor. B. Consecutive section of the same tumor stained with rabbit polyclonal K-18 antibody and anti-rabbit lgG and avidin-biotin peroxidase detection system. Many of the cells exhibited diffuse nuclear staining (2), and insert shows diffuse staining. C. Consecutive section of the same tumor incubated with control rabbit lgG shows no appreciable staining. D. H\&E section of FFPE tissue from patient no.13. E. Consecutive section of the same tumor treated with pressure cooker antigen retrieval and stained with the MS110 antibody showed that many of the cells exhibited weak nuclear staining (1), and insert shows unstained nuclei. F. Consecutive control section of FFPE tissue without primary antibody. $(\times 200)$ insert $(\times 2000)$. 

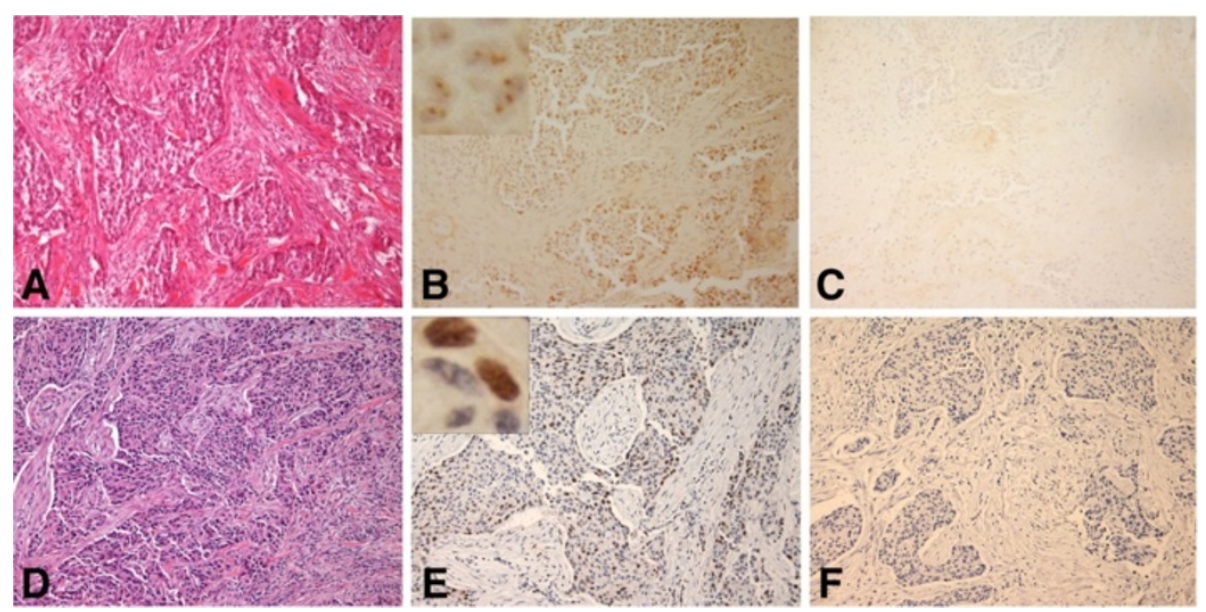

Figure 7 BRCA1 protein localization in frozen and FFPE sections of poorly differentiated adenocarcinoma (PDA) from patient no. 22 using avidin-biotin-detection system. A. H\&E stained frozen section of tumor. B. Consecutive section of the tumor stained with mouse monoclonal AP16 antibody and biotinylated anti- mouse lgG showed that few of the cells showed distinct, punctate nuclear staining (2), and insert shows focal staining. C. Standard dilution of mouse lgG served as negative control. D. H\&E section of FFPE tissue from patient no.22. E. Consecutive section of the same tumor treated with pressure cooker antigen retrieval and stained with the MS110 antibody showed that few of the cells exhibited distinct nuclear staining (2) and insert shows darkly stained and unstained nuclei. $\mathbf{F}$. Consecutive control section of FFPE tissue without primary antibody. (×200) insert (x2000).

note that two PDA samples with moderate or strong BRCA1 staining are ER/PR positive.

We compared immunoperoxidase and immunofluorescence detection procedures to study BRCA1 protein staining in the frozen and FFPE PDA tissue from patient no. 22. With the AP16 antibody and immunoperoxidase detection, many of the tumor cell nuclei showed punctate granular staining of category (2) in the frozen sections (Figure 7). Distinct nuclear staining (2) of many of the tumor cells was found in the contiguous FFPE sections with the MS110 antibody (Figure 7). We then compared immunofluorescence staining with the K-18 antibody on the frozen sections from patient no. 22; BRCA1 protein nuclear localization appeared similar, although there was greater sensitivity with immunofluorescence (Figure 9A). Between 1 and 5 punctate bodies (green) were visible in tumor cell nuclei; the interstitial cell nuclei were only very weakly stained or unstained, although there was intrinsic fluorescence in the stromal tissue. In asynchronously growing MCF7 cells, we found varying staining patterns with the K-18 BRCA1 antibody (Figure 9B). The patterns included strongly fluorescent nuclei, cells with intranuclear punctate bodies, and cells with nuclear and cytoplasmic staining.

12

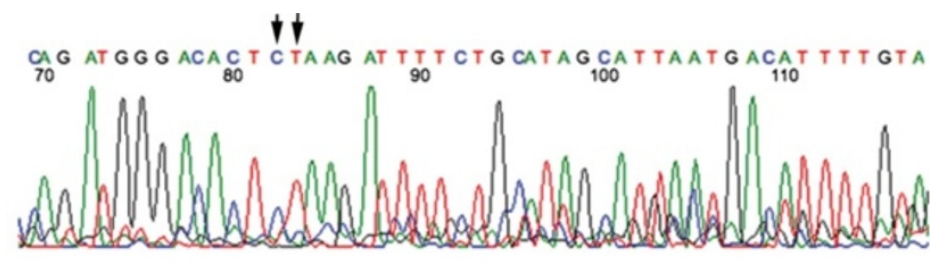

13

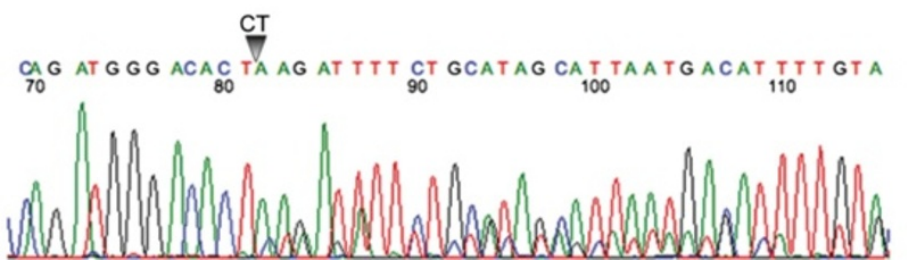

Figure 8 DNA sequencing chromatogram illustrates the mutation, 185delAG, resulting from the deletion of two consecutive nucleotides AG at position $185(\nabla)$ in BRCA1 gene in sample no. 13 (lower panel). DNA sequences from sample no. 12 (wild type) are shown in top panel. Arrows indicate the position of AG deletion. In both, DNA from FFPE tissues were amplified and nucleotide sequences were determined using the primers flanking the mutation loci. 


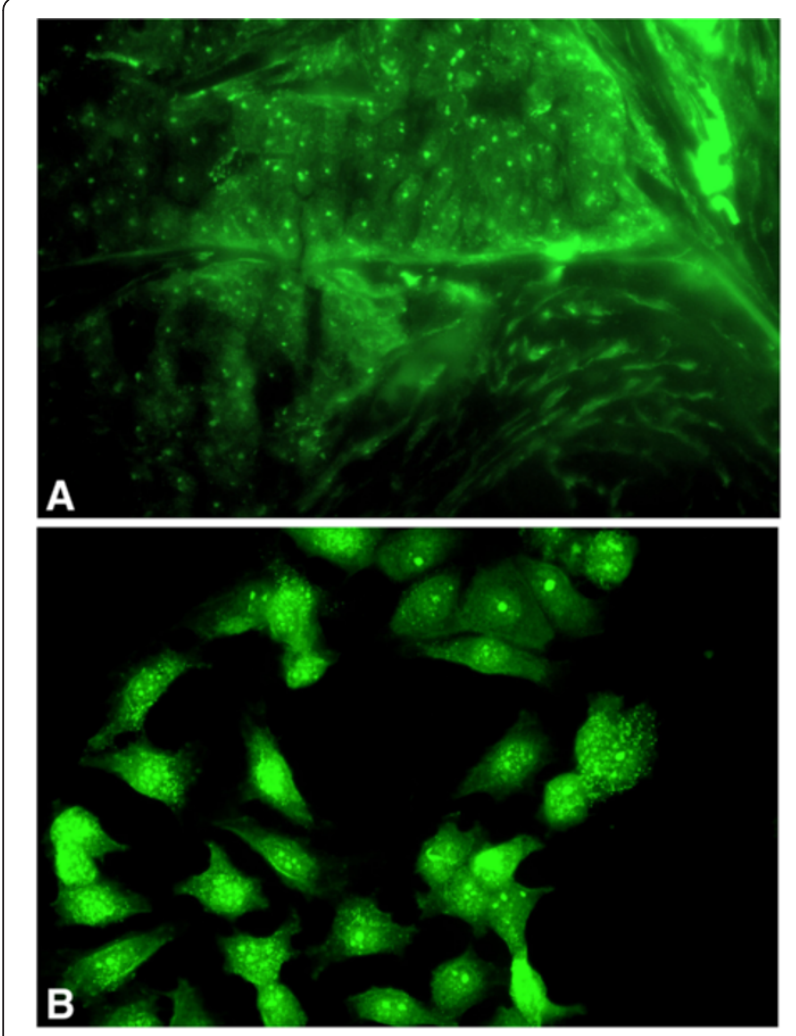

Figure 9 Immunofluorescence staining of BRCA1 protein localization in poorly differentiated adenocarcinoma (PDA) from patient no.22 and an asynchronous culture of MCF7 cells. A. The tumor is stained with rabbit polyclonal K-18 antibody and FITC-labelled goat anti-rabbit serum. Many tumor cell nuclei show both 1-5 punctate bodies (green) and large round central structures (green) and the interstitial cell nuclei are very weakly stained. B. Asynchronous culture of MCF7 cells stained with rabbit polyclonal K-18 antibody and FITC-labelled goat anti-rabbit. BRCA1 staining consisting of fluorescent nuclei, intra-nuclear punctate bodies (green) and cytoplasmic staining. (×300).

We compared BRCA1 and nucleolin co-localization in asynchronously growing MCF7 cells (Figure 10) and HCC1937 cells (Figure 11). The MCF7 cells exhibited varying staining patterns with both antibodies; with the BRCA1 antibody, the nuclear patterns included nuclei with many small dot-like speckles, nuclei with punctate bodies and speckles, and nuclei with round centrally placed bodies (Figure 10A). On the same field, the mouse monoclonal antibody to nucleolin stained nucleoli and many dot-like nuclear speckles (Figure 10B). The colocalization of BRCA1 protein and nucleolin occurred frequently in nucleoli (which are phase dense in Figure 10D) and in some nuclear speckles (Figure 10C). In HCC1937 cells, co-localization of BRCA1 antibody (K-18) and nucleolin 7G2 was found in nuclear speckles, nucleoli, and portions of nucleoli, however, some of the nucleoli, exhibited patches of BRCA1 (green), nucleolin (red), and merged (yellow) regions (Figure 11).
We performed Western blotting to confirm BRCA1 protein levels in MCF7 and HCC1937 cells (Figure 12). Relatively low levels of a $210 \mathrm{kDa}$ BRCA1 species were found in the HCC1937 extracts (5382insC product), compared to the higher levels in control MCF7 extracts (wild-type BRCA1).

\section{Discussion}

We found concordant BRCA1 protein staining in frozen and FFPE tissue specimens of 22 randomly selected breast tumors. Using anti-BRCA1 antibodies AP16 and $\mathrm{K}-18$ on frozen sections we found punctate BRCA1 staining and more homogeneous staining with the MS110 antibody in variable numbers of tumor cell nuclei and nucleoli of breast cancer patients [26,27]. There was variable homogeneous nuclear staining with the MS110 antibody in contiguous pressure cooker antigenretrieved FFPE tumor tissue. These results extend our previous studies which showed BRCA1 nuclear and nucleolar localization in frozen tissue sections and estradioltreated MCF7 cells [26-28]. However, Bogdani et al. [29] using D-20, K-18, I-20, and C-20 anti-BRCA1 antibodies on Bouin's fixed tumor tissue of young and old patients with breast cancer, found nuclear and cytoplasmic BRCA1 staining in about $50 \%$ of sporadic specimens, and less staining in tumor cells in young patients and one with a germline mutation. Perez-Valles et al. [30] showed predominantly cytoplasmic staining with the D-20, I-20, and K-18 polyclonal antibodies in FFPE samples of both tumoral and non-tumoral cells, but nuclear and cytoplasmic staining with the I-20 antibody in FFPE samples after microwave pre-treatment in breast tumor tissue. Recently, Milner et al. [31] in an extensive evaluation of MS110 antibody staining as a patient selection biomarker found sub-cellular localization to the nucleus. However, they concluded that although MS110 did detect BRCA1 in FFPE tumor tissue samples, BRCA1 expression levels in standard methodologies were not reproducible enough to enable its use as a selection marker.

We found less BRCA1 nuclear staining in the tumor tissue of frozen tissue specimens and in contiguous FFPE tissue with higher histological grade. The inverse correlation between lower BRCA1 protein expression and higher histological grade has been well established [24]; less nuclear staining has also been described in estrogen receptor/progesterone receptor/HER2-negative (triple negative) breast tumor tissue [32-34].

In a patient with a BRCA1 mutation (185delAG), we found FFPE tumor tissue stained with the MS110 antibody was mostly negative and the BRCA1 staining in the FFPE normal tissue was weakly positive. These results are consistent with reports showing that heterozygous germline BRCA1 mutations involved in familial breast cancer produce truncated protein, preferential $\mathrm{LOH}$ of 

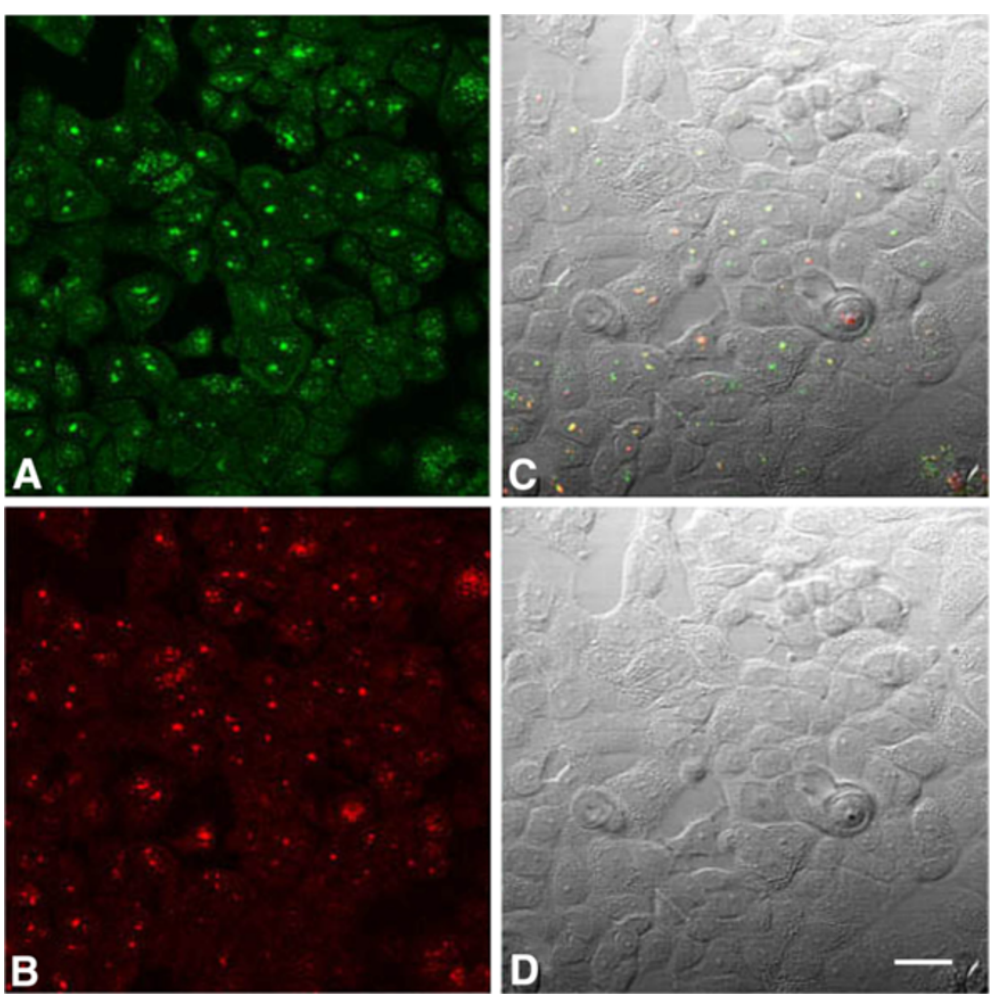

Figure 10 Co-localization of BRCA1 antibody (K-18) and nucleolin (7G2) in MCF7 cells. A. Rabbit polyclonal BRCA1 antibody stains many cell nuclei (green). The varied nuclear patterns include many small dot-like speckles, punctate bodies and speckles, and round centrally placed bodies. B. Mouse monoclonal antibody to nucleolin stains nucleoli and many dot-like speckles (red). C. Nuclei which stain for BRCA1 (green) merge with nucleolin (red) to show co-localization(yellow). The merge occurs both in nucleoli (which are phase dense in D) and in some nuclear speckles. Not all of the nucleoli show co-localization. D. Nomarski image of the same field as A,B,C. Bar $=20 \mu m$.

the wild-type allele in tumor tissue, and loss of MS110 reactivity [35-37]. However, Perez-Valles et al. [29] did not find differences in nuclear BRCA1 protein expression between cases with and without BRCA1 germline mutations by immunohistochemistry.

In our study, we also found diffuse, and irregular BRCA1 protein staining with the $\mathrm{K}-18$ antibody in the frozen section tumor tissue from a patient, with a BRCA1 mutation (185delAG), which is difficult to explain. Although there is no direct evidence that the BRCA1 185delAG mutation results in transcription of a functional truncated protein, Buisson et al. [38] have reported that mRNAs from patients with the BRCA1 185delAG mutations are able to elude the non-sense mediated mRNA decay (NMD) pathway and remain stable in the cell. O'Donnell et al. [39] proposed that the truncated protein product may modulate chemosensitivity. Wilson et al. [24] suggest that the 185delAG mutation results in deletion of most of the protein, including the MS110 epitope which maps between aa residues 89-222. However, the 185delAG BRCA1 N-terminus 39 aa may have an epitope within aa $70-89$ that is detected by the K-18 antibody.
We have found positive BRCA1 protein nuclear staining in frozen and FFPE tumor and lactating tissue from a patient with a BRCA2 mutation. However, as our samples were tested for all three targeted mutations, there is no evidence that $B R C A 1$ is altered in this patient. Therefore these results are consistent with evidence that although BRCA1 protein is a negative regulator of cell growth, BRCA1 expression is up-regulated, during cell proliferation and lactation [40-42].

In our FFPE sections we frequently found that normal epithelial tissue surrounding the tumor had strong nuclear staining with the MS110 antibody, although weak staining was observed in the normal tissue in two of our specimens. This generally agrees with data that normal tissue surrounding the tumor has positive nuclear staining with the MS110 antibody [22]. However, it has also been observed by Bogdani et al. [29] using the I-20 polyclonal antibody that positive nuclear staining was found in $75 \%$ of normal tissue from both young and old patients, and that nuclear staining was absent in the normal tissue of six samples. Milner et al. [31] also found that associated non-neoplastic normal breast epithelium showed moderate to strong nuclear staining with no 



Figure 11 Co-localization of BRCA1 antibody (K-18) and nucleolin (7G2) in HCC1937 cells. A. rabbit polyclonal BRCA1 antibody stains many cell nuclei (green). The varied nuclear patterns include dot-like speckles, and intra-nuclear granules. B. Mouse monoclonal antibody to nucleolin stains nucleoli and many dot-like speckles (red). C. Some nuclear speckles, nucleoli, and portions of nucleoli stain for BRCA1(green) and nucleolin (red) to show co-localization (yellow). The arrow points to a nucleolus, in which there are BRCA1 (green), nucleolin (red), and merged (yellow) regions, which are distinct. D. Nomarski image of the same field as A,B,C. Bar $=20 \mu \mathrm{m}$.

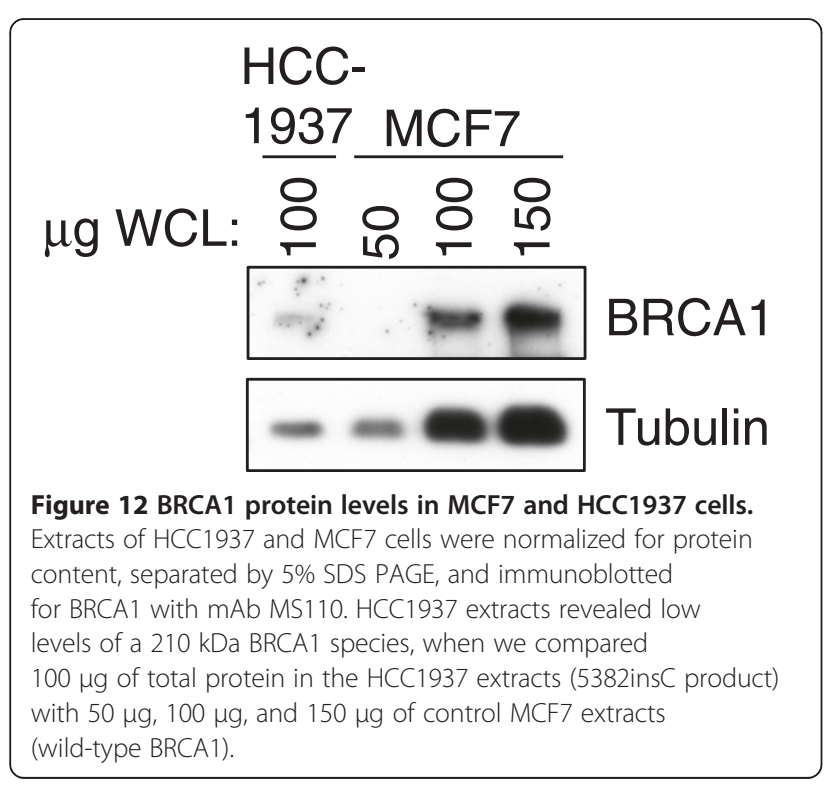

evidence of cytoplasmic staining in normal breast epithelium.

In summary, our immunohistological studies of frozen and FFPE tissues of breast tumors with monoclonal antibodies MS110 and AP16 and the polyclonal antibody K-18, with immunoperoxidase and immunofluorescence detection, have shown that BRCA1 protein has a nuclear and nucleolar localization. We have used freezing in liquid N2, followed by -20o C methanol fixation of the captured frozen sections in order to minimize translocation of antigen during fixation. Guerra-Rebollo et al. [43] also found that after using methanol fixation, BRCA1 was localized in nucleoli, but after $\mathrm{y}$-irradiation BRCA1 was depleted from the nucleolus, and associated with ionizing-radiation induced foci (IRIF).

We have previously shown co-localization of BRCA1 protein and nucleolin in the nucleolus and speckles of MCF7 and HeLa cell nuclei [26,27]. In the present study, we found that in the mutant HCC1937 cell line (5382insC), co-localization of BRCA1 protein and nucleolin occurred in aberrant, patched regions in some nucleoli. HCC1937 extracts revealed low levels of a $210 \mathrm{kDa}$ BRCA1 species consistent with the 
prediction of a truncated protein product lacking the BRCA1 C terminus [44]. This result suggests that protein truncation at the $\mathrm{C}$-terminus may yield variable nucleolar localization. The functions of BRCA1 protein are yet to be fully elucidated, however, BRCA1 protein participates in many signaling pathways involved in transcription, checkpoint control, and is recruited for the formation of DNA repair complexes in association with proteins such as Mre11-Nbs1-Rad50, and BRCA2 [45]. The data that BRCA1 is localized in the nucleolus, in addition to speckles, may explain a possible functional participation in processes of ribosomal biosynthesis, cell cycle progression, and as a reservoir for complexes formed in response to cellular stress and DNA repair $[27,43]$.

The function of BRCA1 protein in tumorigenesis has been found to be complex, and as a tumor suppressor, it is postulated that reduced expression leads to multiple abnormalities, including a defect in the homologous recombination (HR) pathway of DNA repair. These defects are associated with a hypersensitivity to many agents that cause DNA double strand breaks, such as ionizing radiation (IR). In a study testing breast cancer biopsies irradiated ex vivo for the ability to form BRCA1, FANCD2 and RAD 51 foci, Willers et al. [46] detected BRCA1 DNA repair foci defects in triple-negative breast cancers, a phenotype associated with BRCA1 deficiency. In addition, Burga et al. [47] found an association of increased proliferation and increased BRCA1 immunohistochemical expression in breast cancer epithelial cells from BRCA1 mutation carriers, which they ascribed to epidermal growth receptor pathway activation.

The data presented here support a role for BRCA1 in the pathogenesis of sporadic and inherited breast cancers. The use of well-characterized reagents and possibilities for co-localization experiments in both cell culture, and frozen and FFPE tissues, may lead to further insights into the molecular pathways involved in BRCA1 protein function and possibly the further development of targeted therapeutics.

\section{Conclusions}

We compared BRCA1 protein localization in frozen and FFPE tissue, from 22 randomly selected patients with breast carcinomas. We tested 16 of the tumor specimens to determine whether they contained the common Ashkenazi Jewish founder mutations in BRCA1 (185delAG, 5382insC), and BRCA2 (6174delT). Two mutation carriers were identified: patient no. 4 who was a mutation carrier for BRCA2 (6174delT), and patient no. 13 who was a mutation carrier for BRCA1 (185delAG), and were confirmed by gene sequencing.

In the frozen sections, the BRCA1 antibody staining showed punctate, intra-nuclear granules in varying numbers of tumor, lactating, and normal cells In the FFPE tissue, we found reduced BRCA1 nuclear staining in breast tumor tissue compared to normal tissue, and less BRCA1 staining with higher histological grade in the tumors. The differences in staining between frozen and FFPE sections based on a varied group of infiltrating breast tumors, suggest that the sub-nuclear localization of BRCA1 is best studied by comparison of frozen and FFPE sections, using an array of BRCA1 antibodies, and fixation procedures.

We have previously shown co-localization of BRCA1 and nucleolin, and cell cycle dependent BRCA1 nucleolar localization in MCF7 cells. In the present study, we compared co-localization of BRCA1 and nucleolin in MCF7 cells (wild type), and a mutant BRCA1 cell line, HCC1937 (5382insC) and found altered sub-nuclear and nucleolar localization patterns consistent with a functional impact of the mutation on protein localization.

\section{Materials and methods}

This study was approved by the Institutional Review Board of the Mount Sinai School of Medicine. We randomly selected specimens of breast cancer tissue from 22 patients, not screened for ethnicity, which were submitted to the surgical pathology division of the Department of Pathology between 1996 and 2000 and snap froze them in liquid N2. The remainder of the tissue was routinely fixed in formalin and paraffin embedded. Family history, histopathological diagnosis, age of onset, lymph node status, and estrogen, progesterone receptor (ER, PR) status were recorded for each patient and entered into a database. The series of infiltrating breast carcinomas was classified as: ductal, lobular, medullary, colloid, or tubular; and if ductal, was graded moderately differentiated adenocarcinoma (MDA) or poorly differentiated adenocarcinoma (PDA) according to modified Bloom-Scarff-Richardson criteria [48]. Once the clinical data was collected, each patient and corresponding specimen was assigned a number; and our statistician, acting as a third-party liaison assumed responsibility for maintaining the database. DNA results were communicated to the statistician, who then entered the anonymized information into the database.

\section{Primary antibodies}

Mouse monoclonal BRCA1 antibodies: MS110 r 1-304; MS 13 r 1-304; AP 16 r 1,313-1863; and SG 11 r-18461863 (22, Oncogene Research Products, CA); and the K-18 rabbit antibody, r-70-89 [49], Santa Cruz Technology, CA), were prepared at 1:20 dilution. For antigen-retrieved FFPE tissue the MS110 antibody was diluted 1:200. The specificity of the K-18 antibody binding was checked by pre-absorption with the peptide [26], Santa Cruz Technology, CA] and stained in 
parallel with a positive control. For nucleolin staining, mAb 7G2, a mouse monoclonal antibody was used at 1:2 [50], kind gift from S. Pinol-Roma].

\section{Immunohistology}

The methodology for preparing the frozen sections has been described previously [26]. Briefly, tissue snap frozen in liquid $\mathrm{N} 2$ is mounted at about $-8^{\circ} \mathrm{C}$ in oil (an approximately eutectic mixture of aliphatic esters with a freezing point of about $-9^{\circ} \mathrm{C}$ ), frozen at about $-25^{\circ} \mathrm{C}$, and sectioned using a special adhesive tape to capture the section. The section is transferred to a $-13^{\circ} \mathrm{C}$ microscope slide coated with a UV-polymerizable adhesive and treated with a flash of UV to polymerize the adhesive and adhere the section (Leica). The slide-mounted, 6-micron frozen sections were melted at room temperature and air dried for 1 hour before being dipped for 30 to $60 \mathrm{sec}$. in $-20^{\circ} \mathrm{C}$ methanol, and then dried for 5 minutes before being used. Before staining, sections were re-hydrated in PBS, and then incubated in primary rabbit or mouse antibodies. Normal goat serum was used to block nonspecific immunoglobulin binding and the sections were incubated in a humidified atmosphere at $4^{\circ} \mathrm{C}$ for 16 hours. Standard dilutions of normal rabbit or mouse IgG served as negative controls for each experiment. For immuno-peroxidase staining, the avidinbiotin-peroxidase complex technique (Dako Corp., CA) was used. For immunofluorescence, the slides were incubated with species-specific, FITC or TXR-conjugated secondary antibodies for $30 \mathrm{~min}$, at a 1:100 dilution, washed extensively in PBS, and mounted with Vectashield with or without DAPI (4,6-diamidino-2-phenylindole) (Vector Labs., CA). Fluorescently stained cells or tissues were observed using a Zeiss axiophot microscope equipped with a 40X Plan-Neofluar objective, and a Leica TCS-SP (UV) confocal laser scanning microscope.

Paraffin sections were deparaffinized by heating at $60 \mathrm{o}$ $\mathrm{C}$ for $30 \mathrm{~min}$ followed by two 5 -min immersions in $\mathrm{xy}-$ lene. The tissue sections were rehydrated through a graded series of alcohols, followed by two 15 min rinses in distilled water. They were heated in a pressure cooker for four min in $0.05 \mathrm{M}$ citrate buffer ( $\mathrm{pH}$ 5.6). Thereafter, the slides were washed twice for $15 \mathrm{~min}$ each in phosphate buffered saline (PBS) (Sigma). The BRCA1 monoclonal antibody MS110 produced staining of tumor cell nuclei at a 1:200 dilution. The UltraVision LP (ThermoScientific) detection system was used for diaminobenzidine (DAB) staining. Immunoreactivity was qualitatively assessed by the proportion of reactive cells and the intensity of staining: weak, faint (1), distinct (2), moderate (3), and strong (4).

\section{Cell culture}

For the cell studies, MCF7 and HCC1937 [51] were grown in RPMI 1640 supplemented with 10\% heat- inactivated FCS, $50 \mathrm{U} / \mathrm{ml}$ penicillin, and $50 \mu \mathrm{g} / \mathrm{ml}$ streptomycin. The cells were grown on chamber slides, washed three times in PBS, immersed in liquid N2 for 13 seconds, and then followed by 20 minute fixation in $-20^{\circ} \mathrm{C}$ methanol. After a wash in PBS, the slides were incubated in primary rabbit or mouse antibody, or colocalized with both antibodies simultaneously. After subsequent PBS rinses, the slides were incubated with species-specific, FITC or TXR-conjugated secondary antibodies for 30 minutes, at a 1:100 dilution, washed extensively in PBS, and mounted with Vectashield with or without DAPI (Vector Labs., CA). Fluorescently stained cells were observed using a Zeiss axiophot microscope equipped with a 40x Plan-Neofluar objective, and a Leica TCS-SP (UV) confocal laser scanning microscope.

\section{Western blotting}

For biochemical analysis, MCF7 and HCC1937 cells were grown on $100 \mathrm{~mm}$ culture dishes. Subconfluent, asynchronously dividing cells were rinsed once with $5 \mathrm{ml}$ ice cold PBS and lysed in 1\% CHAPS lysis buffer $(150 \mathrm{mM}$ $\mathrm{NaCl}, 10$ mM HEPES, pH7.4, 1\% CHAPS 3- [(3Cholamidopropyl-dimethylammonio-1-propanesulfonate)] supplemented with protease and phosphatase inhibitors. For the detection of BRCA1, $100 \mu \mathrm{g}$ whole cell lysate (WCL) from HCC1937 was compared to 50, 100, and $150 \mu \mathrm{g}$ WCL from MCF7 cells and resolved using 6\% SDS-PAGE. Proteins were then transferred to PVDF membrane, blocked for $1 \mathrm{~h}$ with $5 \%$ nonfat milk in TBS-T (20 mM Tris-CL, pH 8.0, $150 \mathrm{mM} \mathrm{NaCl}, 0.05 \%$ Tween 20 ) at room temperature, incubated with the primary antibody MS110 (AB-1) 1:500 in blocking solution overnight at $4^{\circ} \mathrm{C}$, the membrane was washed three times in TBS-T, the membrane was then incubated with goat anti-mouse (HRP) secondary antibody 1: 4000 for $45 \mathrm{~min}$ at room temperature, washed three times 10 minutes, and proteins were detected using chemiluminescence HRP detection (Millipore).

\section{Genotyping}

DNA from 16 anonymous breast cancer specimens was extracted from frozen tissue. A multiplex (triplex) polymerase chain reaction was performed to amplify fragments for the common Jewish Ashkenazi mutations in BRCA1 (185delAG, 5382insC), and BRCA2 (6174delT). The products were hybridized with normal and mutant probes for each of three mutations as previously described [12]. In accordance with IRB regulations, the anonymized DNA from the two mutation carriers was sent to Myriad Genetics (Salt Lake City, Utah) for gene sequencing. To confirm the BRCA1 185delAG mutation, DNA from FFPE slides of specimen no.13 was isolated using the BiOstic FFPE tissue DNA isolation kit (Mo Bio 
Laboratories) and amplified by PCR using the oligonucleotide primers flanking the mutation loci: BRCA1, 185delAG forward ( $5^{\prime}$-GGATTTATCTGCTCTTCGCG TT-3') and 185delAG reverse (5'-TGTCTTTTCTTC CCTAGTATGT-3'). The PCR product was purified and subjected to DNA sequencing with the primers used for the amplification. As a negative control, DNA from specimen no.12 was amplified and sequenced using the same primers. The sequences were compared with the reference sequences using program BLAST.

\section{Competing interests}

The authors declare they have no competing interests.

\section{Authors' contributions}

NT conceived the study, LO helped to analyze the data, SD, JS, IB, SJ, CN provided samples, histopathological diagnoses, and analyzed data, RK, LE, KB did screening, and analysis for 3 common Ashkenazi mutations BRCA 1 (185delAG, 5382insC) and BRCA2 (6174delT), CB maintained the database and collated the genetic data, VDN did molecular genetic studies on FFPE tissue, MC and ANAM critically revised the manuscript, NTW did the western blotting. All authors read and approved the final manuscript.

\section{Acknowledgements}

Confocal microscopy was performed at the MSSM-Microscopy Shared Research Facility supported, in part, with funding from $\mathrm{NIH-NCl}$ shared resources grant (1R24CAO95823-01). We thank Joseph Samet for help with photography and computer graphics. Leonard Ornstein and Steven Dikman are posthumous.

\section{Author details}

'Department of Pathology, Mount Sinai School of Medicine, 1 Gustave L. Levy Place, New York, NY 10029, USA. ${ }^{2}$ Department of Genetics, Mount Sinai School of Medicine, New York, NY, USA. ${ }^{3}$ Department of Anesthesiology, Mount Sinai School of Medicine, New York, NY, USA. ${ }^{4}$ Department of Neurology, Mount Sinai School of Medicine, New York, NY, USA. ${ }^{5}$ Faculté de Pharmacie, IBMM, Montpellier, France. ${ }^{6}$ Cancer Epidemiology Program, H. Lee Moffitt Cancer Center and Research Institute, Tampa, FL, USA. ${ }^{7}$ Department of Oncological Sciences, Morsani College of Medicine, University of South Florida, Tampa, FL, USA.

Received: 18 December 2012 Accepted: 12 July 2013

Published: 15 July 2013

\section{References}

1. Newman B, Mu H, Butler LM, Millikan RC, Moorman PG, King M-C: Frequency of breast cancer attributable to BRCA1 in a population- based series of American women. JAMA 1998, 279:915-921.

2. Miki Y, Swensen J, Shattuck-Eidens D, Futreal PA, Harshman K, Tavtigian S, Liu Q, Cochran C, Bennett LM, Ding W, Bell R, Rosenthal J, Hussey C, Tran T, McClure M, Frye C, Hattier T, Phelps R, Haugen-Strano A, Katcher H, Yakumo K, Gholami Z, Shaffer D, Stone S, Bayer S, Wray C, Bogden R, Dayanath P, Ward J, Tonin P, Narod S, Bristow PK, Norris FH, Helvering L, Morrison P, Rosteck P, Lei M, Barrett JC, Lewis C, Neuhausen S, Cannon-Albright L, Goldgar D, Wiseman R, Kamb A, Skolnick M: A strong candidate for the breast and ovarian cancer susceptibility gene BRCA1. Science 1994, 266:66-71.

3. Futreal PA, Liu Q, Shattuck-Eidens D, Cochran C, Harshman K, Tavigian S, Bennett LM, Haugen-Strano A, Swensen J, Miki Y, Eddington K, McClure M, Frye C, Weaver-Feldhaus J, Ding W, Gholami Z, Soderkvist P, Terry L, Jhanwar S, Berchuck A, Iglehart JD, Marks J, Ballinger DG, Barrett JC, Skolnick $\mathrm{MH}$, Kamb A, Wiseman R: BRCA1 mutations in primary breast and ovarian carcinomas. Science 1994, 266:120-122.

4. Wooster R, Neuhausen SL, Mangion J, Quirk Y, Ford D, Collins N, Nguyen K, Seal S, Tran T, Averill D, Fields P, Marshall G, Narod S, Lenoir GM, Lynch H, Feunteun J, Devilee P, Cornelisse CJ, Menko FH, Daly PA, Ormiston W, McManus R, Pye C, Lewis CM, Cannon-Albright LA, Peto J, Ponder BJA, Skolnick MH, Easton DF, Goldgar DE, Stratton MR: Localization of a breast cancer susceptibility gene, BRCA2, to chromosome 13q12-13. Science 1994, 265:2088-2090.

5. Tavtigian SV, Simard J, Rommens J, Couch F, Shattuck-Eidens D, Neuhausen S, Merajver S, Thorlacius S, Offit K, Stoppa-Lyonnet D, Belanger C, Bell R, Berry S, Bogden R, Chen Q, Davis T, Dumont M, Frye C, Hattier T, Jammulapati S, Janecki T, Jiang P, Kehrer R, Leblanc JF, Mitchell JT, McArthur-Morrison J, Nguyen K, Peng Y, Samson C, Schroeder M, Snyder SC, Steele L, Stringfellow M, Stroup C, Swedlund B, Swense J, Teng D, Thomas A, Tran T, Tranchant M, Weaver-Feldhaus J, Wong AK, Shizuya H, Eyfjord JE, Cannon-Albright L, Tranchant M, Labrie F, Skolnick MH, Weber B, Kamb A, Goldgar DE: The complete BRCA2 gene and mutations in chromosome 13q-linked kindreds. Nat Genet 1996, 12:333-337.

6. Lindblom A, Skoog L, Rotstein S, Werelius B, Larsson C, Nordenskjold M: Loss of heterozygosity in familial breast carcinomas. Cancer Res 1993, 53:4356-4361.

7. Merajver SD, Frank TS, XU J, Pham TM, Calzone KA, Bennet-Baker P, Chamberlain J, Boyd J, Garber JE, Collins FS: Germline BRCA1 mutations and loss of the wild-type allele in tumors from families with early onset breast and ovarian cancer. Clin Cancer Res 1995, 1:539-544.

8. Lidereau R, Eisinger F, Champeme M-H, Nogues C, Bieche I, Birnbaum D, Pallud C, Jacquemier J, Sobol H: Major improvement in the efficacy of BRCA1 mutation screening using morphoclinical features of breast cancer. Cancer Res 2000, 60:1206-1210.

9. Bell DW, Erban J, Sgroi DC, Haber DA: Selective loss of heterozygosity in multiple breast cancers from a carrier of mutations in both BRCA1 and BRCA2. Cancer Res 2002, 62:2741-2743.

10. Langston AA, Malone KE, Thompson JD, Daling JR, Ostrander EA: BRCA1 mutations in a population-based sample of young women with breast cancer. N Engl J Med 1996, 334:137-142.

11. Streuwing JP, Hartge P, Wacholder S, Baker SM, Berlin M, McAdams M, Timmerman MM, Brody LC, Tucker MA: The risk of cancer associated with specific mutations of BRCA1 and BRCA2 among Ashkenazi Jews. N Engl J Med 1997, 336:1401-1408.

12. Fodor FH, Weston A, Bleiweiss IJ, McCurdy LD, Walsh MM, Tartter PI, Brower ST, Eng CM: Frequency and carrier risk associated with common BRCA1 and BRCA2 mutations in Ashkenazi Jewish breast cancer patients. Am J Hum Genet 1998, 63:45-51.

13. Ozcelik H, To MD, Couture J, Bull SB, Andrulis IL: Preferential allelic expression can lead to reduced expression of BRCA1 in sporadic breast cancers. Int J Cancer 1998, 77:1-6.

14. Sourvinos G, Spandidos DA: Decreased BRCA1 espression levels may arrest the cell cycle through activation of p53 checkpoint in human sporadic breast tumors. Biochem and Biophys Res Comm 1998, 245:75-80.

15. Rio PG, Maurizis J-C, de Latour MP, Bignon Y-V, Bernard-Gallon DJ: Quantification of BRCA1 protein in sporadic breast carcinoma with or without loss of heterozygosity of the BRCA1 gene. Int J Cancer 1999, 80:823-826.

16. Egawa C, Miyoshi Y, Taguchi T, Tamaki Y, Noguchi S: Quantitative analysis of BRCA1 and BRCA2 mRNA expression in sporadic breast carcinomas and its relationship with clinicopathological characteristics. Jpn J Cancer Res 2001, 92:624-630.

17. Guendel I, Carpio L, Pedati C, Schwartz A, Teal C, Kashanchi F, Kehn-Hall K: Methylation of Tumor Suppressor Protein, BRCA1, Influences Its Transcriptional Cofactor Function. PLoS One 2010, 5(6):e11379.

18. Rehman FL, Lord C, Ashworth A: Synthetic lethal approaches to breast cancer therapy. Nat Rev Clin Oncol 2010, 7:718-724.

19. Fong PC, Boss DS, Yap TA, Tutt A, Wu P, Mergui-Roelvink M, Mortimer P, Swaisland H, Lau A, O'Connor MJ, Ashworth A, Carmichael J, Kaye SB, Schellens JHM, de Bono JS: Inhibition of Poly(ADP-Ribose) Polymerase in Tumors from BRCA Mutation Carriers. NEJM 2009, 361:123-134.

20. Henderson BR: The BRCA1 breast cancer suppressor: Regulation of transport, dynamics, and function of multiple subcellular locations. Scientifica 2012, 796808:15.

21. Coene ED, Hollinshead MS, Waeytens AT, Schelfhout VR, Eechaute WP, Shaw MK, Van Oostveldt PMV, Vaux DJ: Phosphorylated BRCA1 is predominantly located in the nucleus and mitochondria. Mol Biol Cell 2005, 16:997-1010.

22. Scully R, Ganesan S, Brown M, De Caprio JA, Cannistra SA, Feunteun J, Schnitt S, Livingston DM: Location of BRCA1 in human breast and ovarian cancer cells. Science 1996, 272:123-125.

23. Chen Y, Chen C-F, Riley DJ, Allred DC, Chen P-L, von Hoff D, Osborne CK, Lee W-H: Aberrant subcellular localization of BRCA1 in breast cancer. Science 1995, 270:789-791. 
24. Wilson CA, Ramos L, Villasenor MR, Anders KH, Press MF, Clarke K, Karlan B, Chen JJ, Scully R, Livingston DM, Zuch RH, Kanter MH, Cohen S, Calzone FJ, Slamon DJ: Localization of human BRCA1 and its loss in high-grade, noninherited breast carcinomas. Nat Genet 1999, 21:236-240.

25. Rakha EA, El-Sheikh SE, Kandil MA, El-Sayed ME, Green AR, Ellis FR: Expression of BRCA1 protein in breast cancer and its prognostic significance. Hum Pathol 2008, 39:857-865.

26. Tulchin N, Ornstein L, Bleiweiss IJ, Mendlowitz M, Weinstein E, Dikman SH: Nucleolar localization of BRCA1 protein in human breast cancer. Int $\mathrm{J}$ Oncol 1998, 13:513-518.

27. Tulchin N, Chambon M, Juan G, Dikman S, Strauchen J, Ornstein L, Billack B, Woods NT, Monteiro ANA: BRCA1 protein and nucleolin colocalize in breast carcinoma tissue and cancer cell lines. Am J Path 2010, 176:1203-1214.

28. Chambon M, Nirde P, Gleizes M, Roger P, Vignon F: Localization of BRCA1 protein in human breast cancer cells. Breast Cancer Res Treat 2003, 79:107-119.

29. Bogdani M, Teugels E, De Greve J, Bourgain C, Neyns B, Pipeleers-Marichal M: Loss of nuclear BRCA1 localization in breast carcinoma is age dependent. Virchows Arch 2002, 440:274-279.

30. Perez-Valles A, Martorell-Cebollada M, Nogueira-Vazquez E, Garcia-Garcia JA, Fuster-Diana F: The usefulness of antibodies to the BRCA1 protein in detecting the mutated BRCA1 gene:An immunohistochemical study. $J$ Clin Pathol 2001, 54:476-480.

31. Milner R, Wombwell H, Eckersley S, Barnes D, Warwicker J, Van Dorp E, Dearden S, Hughes G, Harbron C, Wellings B, Hodgson D, Womack C, Gray N, Lau A, O'Connor MJ, Marsden C, Kvist AJ: Validation of the BRCA1 antibody MS110 and the utility of BRCA1 as a patient selection biomarker in immunohistochemical analysis of breast and ovarian tumors. Virchows Arch 2013, 462:269-279.

32. Jarvis EM, Kirk JA, Clarke CL: Loss of nuclear BRCA1 expression in breast cancers is associated with a highly proliferative tumor phenotype. Cancer Genet Cytogenet 1998, 101:109-115.

33. Welcsh PL, Lee MK, Gonzalez-Hernandez RM, Black DJ, Mahadevappa M, Swisher EM, Warrington JA, King M-C: BRCA1 transcriptionally regulates genes involved in breast tumorigenesis. Proc Natl Acad Sci USA 2000, 299:7560-7565.

34. Hogervorst FBL, Cornelis RS, Bout M, van Vliet M, Oosterwijk JC, Olmer R, Bakker B, Klijn JGM, Vasen HFA, Meijers-Heijboer H, Menko FH, Cornelisse CJ, den Dunnen JT, Devilee P, van Ommen GJB: Rapid detection of BRCA1 mutations by the protein truncation test. Nat Genet 1995, 110:208-212.

35. Osorio A, de la Hoya M, Rodriguez-Lopez R, Martinez-Ramirez A, Cazorla A, Granizo JJ, Esteller M, Rivas C, Caldes T, Benitez J: Loss of heterozygosity : analysis at the BRCA loci in tumor samples from patients with familial breast cancer. Int J Cancer 2002, 99:305-309.

36. Shattuck-Eidens D, McClure M, Simard J, Labrie J, Narod S, Couch F, Hoskins K Weber B, Castilla L, Erdos M, Brody L, Friedman L, Ostermeyer E, Szabo C, King MC, Jhanwar S, Offit K, Norton L, Gilewski T, Lubin M, Black D, Boyd M, Steel M, Ingles $S$, Haile R, Lindblom A, Olsson M, Borg A, Bishop T, Solomon E, Radice P, Spatti G, Gayther S, Ponder B, Warren W, Stratton M, Liu Q, Fujimura F, Lewis C, Skolnick MH, Goldgar DE: A collaborative survey of 80 mutations in the BRCA1 breast and ovarian cancer susceptibility gene. Implications for presymptomatic testing and screening. JAMA 1995, 273:535-541.

37. Malone KE, Daling JR, Thompson JD, O'Brien CA, Francisco LV, Ostrander EA: BRCA1 mutations and breast cancer in the general population. Analyses in women before age 35 years and in women before age 45 with firstdegree family history. JAMA 1998, 279:922-929.

38. Buisson M, Ancsuko'w O, Almoutassem B, Zetoune MD, Mazoyer S: The 185delAG mutation(c.68_69delAG) in the BRCA1 gene triggers translation reinitiation at a downstream AUG codon. Human Mut 2006 27:1024-1029.

39. O'Donnell JD, Linger RJ, Kruk PA: BRCA1 185 del AG mutant protein BRAt, up-regulates maspin in ovarian epithelial cells. Gynecol Oncolog 2010, 116:262-268.

40. Holt J, Thompson ME, Szabo C, Robinson-Benion C, Arteaga CL, King M-C, Jensen RA: Growth retardation and tumor inhibition by BRCA1. Nat Genet 1996, 12:298-302.

41. Thompson ME, Jensen RA, Obermiller PS, Page DL, Holt JT: Decreased expression of BRCA1 accelerates growth and is often present during sporadic breast cancer progression. Nat Genet 1996, 9:444-450.

42. Hakem R, De la Pompa JL, Sirard C, Mo R, Woo M, Hakem A, Wakeham A, Potter J, Reitmar A, Bilia F, Firpo E, Hui CC, Roberts J, Rossant J, Mak TW: The tumor suppressor gene BRCA1 is required for embryonic cellular proliferation in the mouse. Cell 1996, 85:1009-1023.

43. Guerra-Rebollo M, Mateo F, Franke K, Huen MS, Lopitz-Otsoa F, Rodriguez MS, Plans V, Thomson TM: Nucleolar exit of RNF8 and BRCA1 in response to DNA damage. Exp Cell Res 2012, 318(18):2365-2376.

44. Scully R, Vlasakova K, Chen JH, Sokolovsky M, Livingston DM: Genetic analysis of BRCA1 function in a defined tumor cell line. Mol Cell 1999, 4:1093-1099.

45. Xie A, Kwok A, Scully R: Role of mammalian Mre11 in classical and alternative nonhomologous end joining. Nature Struct Mol Biol 2009, 16:814-818.

46. Willers H, Taghian AG, Luo C-M, Treszezamsky A, Sgroi DC, Powell SN: Utility of DNA repair foci for the detection of putative BRCA1 pathway defects in breast cancer biopsies. Mol Cancer Res 2009, 7:1304-1309.

47. Burga LN, Tung NM, Troyan SL, Bostina M, Konstantinopoulos PA, Fountzilas H, Spentzos D, Miron A, Yassin YA, Lee BT, Wulf GM: Altered proliferation and differentiation properties of primary mammary epithelial cells from BRCA1 mutation carriers. Cancer Res 2009, 69:1273-1278.

48. Association of Directors of Anatomic and Surgical Pathology: Recommendations for the reporting of breast carcinoma. Mod Pathol 1996, 9:77-81.

49. De Petrocellis L, Melck D, Palmisano A, Bisogno T, Laezza C, Bifulco M, D Marzo $\mathrm{V}$ : The endogenous cannabinoid anandamide inhibits human breast cancer cell proliferation. Proc Natl Acad Sci USA 1998, 95:8375-8380.

50. Pinol-Roma S: Association of non-ribosomal nucleolar proteins in ribonucleoprotein complexes during interphase and mitosis. Mol Biol Cell 1999, 10:77-90.

51. Tomlinson GE, Chen TT-L, Stastny VA, Virmani AK, Spillman MA, Tonk V, Blum JL, Schneider NR, Wistuba II, Shay JW, Minna JD, Gazdar AF: Characterization of a breast cancer cell line derived from a germ-line BRCA1 mutation carrier. Can Res 1998, 58:3237-3342.

\section{doi:10.1186/1475-2867-13-70}

Cite this article as: Tulchin et al:: Localization of BRCA1 protein in breast cancer tissue and cell lines with mutations. Cancer Cell International 2013 13:70

\section{Submit your next manuscript to BioMed Central and take full advantage of:}

- Convenient online submission

- Thorough peer review

- No space constraints or color figure charges

- Immediate publication on acceptance

- Inclusion in PubMed, CAS, Scopus and Google Scholar

- Research which is freely available for redistribution 